\title{
Investigating the Human Capital Accounts for a Variation in Desistance and Its Relative Impact on Desistance at the Louisiana State Penitentiary
}

\author{
Geraldine Doucet \\ Department of Criminology \& Criminal Justice \\ Nelson Mandela College of Government and Social Sciences \\ Southern University and A \& M College, Baton Rouge, Louisiana
}

\begin{abstract}
This study investigates the human capital accounts for a variation in desistance and its relative impact on desistance at the Louisiana State Penitentiary. The study used a survey research design, binary logistic regression, and a primary data source to investigate the study. A sample size of 144 inmates were surveyed for the purposes of analysis. The primary data source comes from the Louisiana State Penitentiary based on self-reported face-tofact survey interviews initially taken May 2007 and followed by face-to-fact interviews officially obtained data over the period of a year and eight months regarding the same sample population. Results suggested that in the Before study, using self-reported data, that human capital variables were not statistically reliable in distinguishing desistance among the sample of aged delinquents at 5\% significance level, but tend to be statistically reliable in distinguishing desistance among the sample of aged delinquents at $10 \%$ significance level. The After-study results showed no predictability with respect to desistance among any of the predictor variables. Among all the regression variables such as religion, education, past and present education, mental health, and punishment adjustment in the human capital account analysis, only punishment adjustment was statistically significant at $5 \%$ and $10 \%$ significance levels with a $p$-value of $0.006(p<0.05)$. The study further revealed in the analysis that all the nine human capital variables, adjustment [LSAC1] was three times more likely to predict the desistance process. In other words, an aged delinquent offender who adjusts to prison is 3.12 times more likely to have a decrease in anti-social behavior than an aged delinquent who did not adjust to prison.
\end{abstract}

Keywords: Desistance, Delinquents, Crime, Juvenile, Punishment, Incarceration, Human Capital, Social Capital, Sanction.

DOI: $10.7176 / \mathrm{JLPG} / 112-15$

Publication date:August $31^{\text {st }} 2021$

\section{INTRODUCTION}

The U.S. Census Bureau (2001) and the Office of Justice Statistics (OJJDP, 1999), estimate that between 1995 and 2015 , the population that will be at the greatest risk for delinquency is expected to increase by 22 percent. It has been well documented that crime rates follow the proportion of young people, especially males in the population (Siegel, Welsh, \& Senna, 2003; Mukherjee,1997; Kanazawa, 2008). In other words, the higher the proportion of young men in the population, the higher the crime rates will escalate.

Arrest data and self-reported surveys reveal that crime rates rise rapidly during adolescence, peak at age 18, and drop rapidly thereafter (O'Shaughnessy, 2004; Shalala, 2001; Tolan \& Gorman-Smith, 1998; Loeber, Farrington, \& Waschbusch,1998; Kelley, Huizinga, Thornberry, \& Loeber, 1997; Moffitt, 1993; Tolan, 1987). Several studies showed that with this group increasing in population, it is safe to predict that as the number of young males in the population increases, so too will the rise in crime (Blumstein \& Cohen, 1987; Mukherjee, 1997; Kanazawa, 2008). Additionally, with no end in sight for our use of the "get tough on juvenile crime" strategy, it is likely that more teens committing serious offenses will be transferred to adult courts and sentenced to adult prison systems (Van Patten, 1995; Larson, 1997), oftentimes for the rest of their lives, as is the case in Louisiana. In rare instances, the most violent offenders cannot be rehabilitated within the juvenile system and thus are subject to transferred for adult prosecution (Redding, 2008; OJJDP, 2008).

Researchers must use caution when forecasting, particularly of juvenile crime based on the Several spike in homicide rates, which proved to be misleading and highlights the caution with which predictions of future juvenile crime trends must be made. Uncertainty can be built into crime forecasts by adapting and applying the high, medium, and low-scenario approach widely employed in demography research. For example, using highlow projection cones (the range of predictions between the low and high scenario), the scary forecasts of a new wave of juvenile homicide offenders in the first decade of the twenty-first century, made by some researchers (Wilson, Dilulio, and Fox) in the mid-1990s, are shown to be relatively implausible (Commission on Behavior and Social Sciences \& Education, 2001). In fact, more recently, Hockenberry (2020) reports this very point, which is that the 2017 Census of Juveniles in Residential Placement (CJRP) shows that the number of youths in placement actually declined. Hockenberry further points out that between 1997 and 2017, the number of youths 
in residential placement decreased $59 \%$ to 43,580 , its lowest level since the data collection began in 1997 when 105,055 youth were held in out-of-home placement. The number of public facilities decreased $12 \%$ between 1997 and 2017, compared with 58\% for private facilities. Nonetheless, despite this, the decrease in the number of juvenile offenders held at public facilities was slightly greater than the decrease in the number held in private facilities during the same period (down 59\% and 57\%, respectively).

A growing number of studies has identified few factors, such as a positive marriage, parenting, military, education, and steady employment (usually when in the community), as likely causes prompting positive change and desistance (Wilson, 1983; Sampson \& Groves, 1989; Cullen, 1994; Currie,1998; Laub, Nagin, \& Sampson, 1998). These studies, however, have focused on adults, and it is not known whether the same or comparable factors affect incarcerated juveniles similarly. Studies have also shown that sanctions or interventions can have an impact on desistance by altering the offender's human and social capital (McShane \& Williams III, 1989; Cesaroni, \& Peterson-Badali, 2005; Mulvey, Steinberg, Cauffman, Piquero, Chassin, Brame, Schubert, Hecker, \& Losoya, 2004). It has also been observed in the literature that long-terms of incarceration remove an individual from involvement in the job market and increase the likelihood of delinquent behavior (Mulvey, et al., 2004; Fagan \& Freeman, 1999; Sampson \& Laub, 1995). However, it is not clear in the literature on how human capital variables of personal agency-such as life experiences, unique psychological capacities, collective attitudes, religion- beliefs or values, employment skills, training, education attainment and knowledge, could be described as predictors of desistance. Therefore, this current investigates the impact of human capital accounts on the variations in desistance at the Louisiana State Penitentiary (LSP) to inform criminal justice reforms policy.

\section{LITERATURE REVIEW}

Employment and Education

Researchers (Farrall, 2002; Committee on Law \& Justice, 2007) have found that employment and family relationship experiences were more critical to successful desistance than differences in probation practice. Researchers, such as Sampson and Laub (1990; 1993), and Nagin and Waldfogel (1998) found that work is a primary feature of successful reintegration into society and desistance from crime. Comprehensive reviews of dozens of individual program evaluations have suggested that adult academic and vocational programs lead to reduced recidivism (MacKenzie, 2006) and to an increased employment rate of 5-10 percent (Gaes, Flanagan, Motiuk, \& Stewart, 1999); Cullen \& Gendreau, 2000; Wilson, Gallagher, \& MacKenzie, 2000); Aos, Miller, \& Drake, 2006) cited in Committee on Law \& Justice, 2007). In the United States, adult corrections facilities have a long history of providing education and vocational training as part of the rehabilitation process (Piehl, 1998; Gaes et al., 1999; cited in Committee on Law \& Justice, 2007), based on the belief that improving education and job skills will promote desistance (Committee on Law \& Justice, 2007).

\section{The Role of Human and Social Capital in Desistance}

Change in the individual's sense of personal agency (or human and social capital) will affect the process in making the commitment to refrain from anti-social activities. Several investigators contend that a variety of life events may initiate the desistance process, but that the ultimate outcome of these changes' rests on the person's cognitive shifts about who they are as the desistance process unfolds (Giordano, Cernkovich, \& Rudolph, 2002). For example, in the case of serious juvenile offenders, this might mean the continued resolve to avoid certain peers, places, or activities or to attend vocational training classes, or become involved in prison approved inmate organizations. The factor that contributes to the newly developed discipline to carry out such commitment is the development of new and supportive social networks of family and friends, even during incarceration. The ongoing interaction between personal resolve and the restructuring of social ties could provide a richer view of personal agency carried out through conscious alterations of social context and daily activities, which prompts desistance (Mulvey et al., 2004).

Incarcerated aged-delinquents are still developing intellectually and psychosocially, in late adolescence, and the type of changes that occur during this period have considerable relevance for the process of desistance (Mulvey et al., 2004). As aged-delinquents acquire abilities to interpret and handle social situations, acquire skills, and experience personality changes; their goals and aspirations change. Psychosocial characteristics and technical skills are all important for decision making, which increases over the course of adolescence (Steinberg \& Cauffman, 1996; Steinberg, Chung, \& Little, 2004).

A juvenile offender's attitudes, beliefs, and values change considerably between the time of his admission to prison as an adolescent and years into adulthood. They develop a stronger sense of identity and increased psychosocial maturity, their attitude and personal responsibility, altruism, views of others, and the value of risktaking and sensation-seeking behavior may change (Steinberg \& Cuffman, 2000). It is also important to recognize how adolescents' perceptions of, and attitudes toward the legal system change over this developmental period. Research on adults indicates that perceptions regarding procedural justice (Tyler \& Huo, 2002) play an influential role in decisions to obey the law (Tyler, 1990; Tyler, Boeckmann, Smith, \& Huo, 1997).). Such 
perceptions may redirect their views on the legal, social, moral, and personal benefit of crime or anti-social behavior (Grasmick \& Bursik, 1990). It is important to measure the changes in how the juvenile offender now views the costs and benefits of crime. Presumably, as adolescents mature into adulthood, their appraisal of the relative costs and benefits of offending changes in ways that promote desistance (Mulvey, et al., 2004).

Changes in social contexts (an exogenous variable), which include social investments (whom they spend their time with or associate with) bring about many shifts in roles. The juvenile offenders may become involved in positive social relationships, as they mature and their abilities to relate to others in a more positive manner emerge. Late adolescence is usually marked by some basic, yet predictable, shifts in association and how adolescents spend their time. These changes in social contexts may alter opportunities and incentives to prosocial and anti-social activity. Some of these changes may be deliberate attempts to alter opportunities, whereas others may be related to changes in social roles that accompany late adolescence and young adulthood, such as enrollment in college, employment or marriage. Also, during late adolescence there is often a period of change in the family context, such as becoming autonomous by moving out of the parents' home. Though becoming autonomous is an important developmental phase in late adolescence, it is just as vital to maintain a healthy attachment with parents (Allen, Aber, \& Leadbeater, 1990; Steinberg \& Morris, 2001). Now, the youth is less subject to parental control, supervision, and mentoring (Gorman-Smith, Tolan, \& Henry, 2000). This move becomes critical to watch because of the centrality of parental involvement in some of the more successful interventions for delinquency (Cunningham \& Henggeler, 1990).

Shifts in social roles expand when one leaves high school or moves away from home and the neighborhood. New roles in the community also open up during late adolescence and early adulthood due to work, civic involvement, and church membership. Each shift in social contexts brings redefined or new social relationships and expectations regarding the acceptability of anti-social behavior. Successful adjustment to new demands in some of these contexts may promote desistance (i.e., marriage, parenthood, and employment), whereas changes in other social contexts (i.e., moving out of parents' home) may promote continued anti-social activities. These changes provide naturally occurring turning points for young adolescents, and failure to capitalize on them can limit future opportunities (Mulvey et al., 2004).

Desistance from anti-social activity requires a supporting structure for positive activities, and this can exist only if the aged-delinquent offender has the necessary building blocks for its construction. These building blocks are the human and social capitals. More specifically, these are the individual and contextual changes outlined above that might promote desistance and thereby facilitate the successful transition to young adulthood and, eventually to a law-abiding citizen. It is the accumulation of human and social capital during late adolescence that makes the successful transition to young adulthood, and desistance from anti-social activities possible (Mulvey, et al., 2004). In sum, among some predictors of desistance found in the literature are: an intact marriage, healthy/strong parenthood, steady employment, education, age or maturity, community/organizational membership or involvement, a traumatic life experience (like the death of a loved one), involvement in treatment programs (multiple systemic therapy, family therapy, cognitive behavioral therapy) and sanction (incarceration).

\section{METHODOLOGY}

This study follows a correlational research design. A sample size of 144 respondents were used in this study. A disproportionate-stratified probability sampling method utilizing a random number table will be applied. This study consists of two phases (the Before and the After study). The key variable used to predict the variation in desistance in this particular study is human capital and adjustment of punishment for the purpose of analysis. The key variable was measured in a Before self-reported study on May 2007 and an After official-report study on December 2008. The Before data were obtained from a self-reported survey given to inmates at LSP in May 2007. The After data were obtained from official reports provided by LSP's Classification Department. Additionally, violent aged-delinquent male offenders serving life sentences without the benefit of parole prior to age of 18 and up to age 21 were the main population of interest in this study. Aged juvenile delinquents fall into two age categories, juveniles who were 18 to 21 years old at the time of their crimes and juveniles who were 17 years old or younger.

For the purpose of this study, the age group of 18-21 are referred to as young adult lifers (McShane \& Williams, 1989; Capaldi, \& Patterson, 1996). The survey instrument used, LSP Aged-Delinquent Questionnaire, was modeled from a previous survey, Old Prisoner Questionnaire, designed by Dr. James Marquart, Corrections expert researcher. This survey as well as the previous survey was designed for the incarcerated inmate population to obtain a variety of questions related to their past and present lifestyle (family, beliefs/attitude, health behavior, prison adjustment, education, criminal history, etc.) prior to their incarceration and since their incarceration. Based on the desistance literature review, modifications of the instrument were made.

As part of the survey design, a self-designed, detailed questionnaire (LSP Aged Delinquent Questionnaire) was used to conduct the face-to-face interviews. In administering the survey instrument, inmates were gathered into classroom settings or meeting areas and were asked to complete the survey (using the special designed $L S P$ 
Aged Delinquent Questionnaire). The survey required approximately 25 to 30 minutes for completion. The purpose and instructions for taking the survey were personally given by the author of this study with all inmates volunteering to participate in this project.

Statistical techniques utilized in this study were descriptive statistics, nonparametric chi-square, and logistic regression. Descriptive statistics were used to identify and describe the sample population and their self-reported responses. Chi-square statistics were performed to measure the significant difference between desisters and nondesisters among juvenile lifers and young adult lifers (in the sample aged delinquent population). Logistic regression is a statistical procedure used to examine the relationship and predictability of a criterion variable that is categorical from two or more predictor variables. The value that is being predicted in logistic regression is actually a probability, which ranges from 0 to 1 . More precisely, logistic regression specifies the probabilities of the particular outcomes for each participant or case involved.

In this study binary logistic regression was used to predict desistance or non-desistance among aged delinquents based on selective factors. Since desistance is a dichotomous criterion variable, logistic regression is appropriate in identifying the differences within the age-delinquent offenders who desist and those who do not desist. The predictor variables for analyses included punishment (or prison sanction), and human capital variables of personal agency -such as life experiences, unique psychological capacities, collective attitudes, religion- beliefs or values, employment skills, training, education attainment and knowledge.

A model with more than one binary or dichotomous predictor variables can be represented as:

$$
\operatorname{Prob}(\mathrm{Y})=\frac{\mathrm{e}^{\mathrm{z}}}{1+\mathrm{e}^{\mathrm{z}}}
$$

Where $\mathrm{Z}$ is the linear combination, $\mathrm{Z}=Z=\beta_{0}+\beta_{1} X_{1}+\beta_{2} X_{2}+\cdots+\beta_{\mathrm{p}} X_{\mathrm{p}}$

$\mathrm{B}_{0}, \mathrm{~B}_{1}{ }^{\prime} \ldots \ldots, \mathrm{B}_{\mathrm{P}}$ are coefficients estimated from the data and $\mathrm{e}$ is the base of the natural logarithms. When plotted, the logistic regression curve should be shallow with a slope close to zero for very high and very low values of $\mathrm{X}$. If $\mathrm{X}$ and $\mathrm{Y}$ are related, then between the very high and very low values of $\mathrm{X}$ the slope of the curve will be steeper. This means it is significantly different from zero (Menard, 1995).

\section{DATA ANALYSIS AND FINDINGS}

The binary logistic regression procedure was conducted to determine which human capital predictor variables, which consisted of religion, education, employment, mental and emotional health, and adjustment to prison since at LSP, were the predictors of the desistance process. The religion question asked about how often do you (the inmate) attends religious services. This question had more to do with their beliefs as opposed to fellowship or association with other members. Two of the education items asked participants how many years of schooling have they had and whether they were currently enrolled in any schools, colleges, or programs from which they would receive any degree or diplomas.

There were three employment questions. One was regarding their employment status and income prior to incarceration. Question two asked about their annual income prior to incarceration. The third employment question asked respondents to identify the kind of work they performed. The final series of human capital questions addressed their mental or emotional health, punishment adjustment and attitudes. The mental health questions asked respondents to describe their mental or emotional health before and since their conviction and admission to LSP (inquiring about their condition at the time of the study). The last three human capital items addressed how respondents have adjusted to LPS since their admission. Regression results showed that the overall model of the nine human capital predictors (religion, education, past and present education, mental health, and punishment adjustment) were not statistically reliable at 5\% significance level but significance at $10 \%$ significance level to distinguish between desistance (or anti-social behavior) and non-desistance (non-anti-social behavior) among aged delinquents with a Chi Square $=16.281, d f=9, p>.05, p>.10$ (See Table 3).

Table 1

Overall Model Fit Result

\begin{tabular}{lcccc}
\hline & \multicolumn{1}{c}{ Log } & & \\
\multicolumn{1}{c}{ Model } & Likelihood & Chi Square & $D f$ & $P$ \\
\hline $\begin{array}{l}\text { Intercept } \\
\text { Final }\end{array}$ & 168.390 & 16.281 & 9 & $.061^{*}$ \\
\hline
\end{tabular}

$\mathrm{x}^{2}=16.281, d f=9, p=.061$, Cox and Snell R Square $=0.107$, significant at $10 \%$

In relation the Cox and Snell R Square value of 0.107 , it is important to discuss that about $10.7 \%$ variation in desistance could be explained by the variations in the human capital variables or accounts of personal agency. According to Wald Criterion (See Table 2), of all the nine human capital variables, adjustment [LSAC1] was three times more likely to predict the desistance process. In other words, an aged delinquent offender who 
adjusts to prison is 3.12 times more likely to have a decrease in anti-social behavior than an aged delinquent who did not adjust to prison (see Table 2). The remaining odd-ratios for the other eight human capital variables indicated little change in the likelihood of desistance process as previously mentioned. This is because they were not statistically significant at either $5 \%$ significance levels or $10 \%$ significance levels. That is, all their associated p-values are all greater than 0.05 and 0.10 (see Table for more details).

Table 2

Human Capital Model of Logistic Regression for the Log Odds of Desistance

\begin{tabular}{|l|c|c|c|c|cc|}
\hline \multicolumn{1}{|c|}{ Variable } & $\mathrm{B}$ & $\mathrm{SE}$ & Wald & $D f$ & $P$ & Exp(B) \\
\hline Religion & .040 & .118 & .112 & 1 & .737 & 1.040 \\
\hline Education (years of) & .168 & .107 & 2.469 & 1 & .116 & 1.183 \\
\hline Education (current enrollment) & -.133 & .388 & .117 & 1 & .733 & .876 \\
\hline Employment (before LSP) & -.243 & .221 & 1.214 & 1 & .271 & .784 \\
\hline Employment (income) & .016 & .033 & .221 & 1 & .638 & 1.016 \\
\hline Employment(type of work) & -.010 & .138 & .005 & 1 & .943 & .990 \\
\hline Mental health before LSP & .055 & .250 & .048 & 1 & .826 & 1.057 \\
\hline Mental health now & -.214 & .406 & .279 & 1 & .598 & .807 \\
\hline Adjustment (since LSP) & 1.149 & .422 & 7.415 & 1 & $.006^{* *}$ & 3.156 \\
\hline
\end{tabular}

Model $\mathrm{X}^{2}=16.281, \mathrm{df}=9, \mathrm{p}=.61$ Cox and Snell R Square $=.107$, Overall Correct $=68.8$

\section{CONCLUSION AND POLICY IMPLICATION}

In the Before study, which was based on self-reported data form the aged-delinquents themselves, human capital variables were not statistically reliable in distinguishing among desistance aged delinquents (juvenile lifer offenders and young adult lifers) at 5\% significance level but the story changes at $10 \%$ significance level since the overall model significance $\mathrm{p}$-value of 0.061 is less than $0.10(\mathrm{p}<0.10)$. However, in both the human capital variables and the punishment variables categories, adjustment (psychological) to prison variables was statistically reliable in distinguishing desistance among young adult lifers and juvenile lifer offenders. Deductively, it was observed from the model that only one human and punishment variable (adjustmentpsychological) were statistically significant for predicting desistance among the sampled aged delinquents.

The findings from this study does suggest that some of the same variables predicting adult desistance (intimate family relationship, particularly with the nurturer-mother or care takes) are also significant in predicting desistance among violent aged-delinquents serving life sentences. The findings also showed that the older aged delinquents (young adult lifers) desisted at a greater rate than the younger group (juvenile lifer offenders). These findings are also consistent with the earlier works of McShane and Williams (1989). Punishment adjustment variable was the strongest predictor of desistance among all of the variables in this study. Thus, any regression model used to predict desistance among aged delinquent offenders (or juvenile inmates in adult prisons) in the future should include these variables (mother, care-takes relationships, and punishment adjustment) found to be statistically significant in this study. In conclusion, it was observed from the analysis that some of the findings regarding some of the human capital variables (i.e., employment, education, and religion) were inconsistent with the previous literature. A plausible explanation for the current findings may be that predictors such as education, employment skills, and training were not well established prior to the ageddelinquent's LSP admission because they had not yet begun occupational or educational careers due to their chronological ages. It may also be possible that even at early ages, they were not able to secure teen employment because of school drop-out or failure.

This study not only provides some insight to the desistance from anti-social behavior among ageddelinquents, but it also explores the effect of the "get tough" policy on juveniles incarcerated as adults. Whether getting away from the "get tough" policy is beginning to gain favor with politicians and the public, especially with the high economic costs of incarceration, and whether punitive policies toward juvenile offenders have been effective (The Future of Children, 2008), this will not likely affect the seriously violent offenders. Since the use of incarceration is unlikely to decrease for this population, research on effects of adult prison on juveniles is urgently needed (Bonta \&Gendreau, 1990).

\section{REFERENCES}

Allen, J. P., Aber, J. L., \& Leadbeater, B. J. (1990, September). Adolescent problem behaviors: The influence of attachment and autonomy. Psychiatric Clinics of North American, 13(3), 455-467.

Aos, S., Miller, M., \& Drake, E. (2006). Evidence-Based Public Policy Options to Reduce Future Prison Construction, Criminal Justice Costs, and Crime Rates. Olympia: Washington State Institute for Public Policy. Chicago Press.

Blumstein, A., Cohen, J., (1987, August). Characterizing criminal careers. Science, 237(4818), 985-991. 
Bonta, J. \& Gendreau, P. (1990). Reexamining the cruel and unusual punishment of prison life. Law and Human Behavior, 14(4), 347-372.

Capaldi, D.M., \& Patterson, G.R. (1996). Can violent offenders be distinguished from frequent offenders? Prediction from childhood to adolescence. Journal of Research in Crime and Delinquency 33: 206-231.

Cesaroni, C. \& Peterson-Badali, M. (2005). Young offenders in custody: Risk and adjustment. Criminal Justice and Behavior, 32, 251-1277.

Committee on Law \& Justice. (2007). Parole, desistance from crime, and community integration. Washington, DC: The National Academies Press.

Commission on Behavior and Social Sciences and Education. (2001). Juvenile crime: Juvenile justice. McCord, Wisdom, \& Crowell (Eds.) Washington, DC: National Academic Press.

Cullen, F. (1994). Social support as an organizing concept for criminology: Presidential address to the Academy of Criminal Justice Sciences. Justice Quarterly, 11, 527-259.

Cullen, F.T., \& Gendraeu, P. (2000). Assessing correctional rehabilitation pp. 109-175. In Horney (Eds.), Policy, practice, and prospects. Washington, DC: U.S. Department of Justice, National Institute of Justice.

Cunningham, P., \& Henggeler, S. (1999). Engaging multiproblem families in treatment: Lessons learned throughout the development of multisystemic therapy. Family Process, 38, 265-281.

Currie, E. (1998). Crime and punishment in America. New York: Henry Holt.

Fagan, J. \& Freeman, R. (1999). Crime, work, and unemployment. In M. Tonry (Ed.), Crime and justice: A review of research (pp. 225-290). Chicago: University of Chicago Press Journals

Farrall, S. (2002). Rethinking what works with offenders: Probation, social context and desistance from crime. Willan Cullompton Publisher.

Gaes, G. G., Flanagan, T. J., Motiuk, L. L., \& Stewart, L. (1999). Adult Correctional Treatment. In M. Tonry and J. Petersilia, (Eds)Prisons: Crime and Justice: A Review of Research, 26., 361-426, Chicago: University of Chicago Press Journals.

Giordano, P., Cernkovich, S. A. \& Rudolph, J. L. (2002). Gender, crime, and desistance: Toward a theory of cognitive transformation. American Journal of Sociology, 107, 990-1064.

Gorman-Smith D, Tolan, P. H. Henry, D. B. (2000). A developmental-ecological model of the relation of family functioning to patterns of delinquency. Journal of Quantitative Criminology ,16:169-198.

Grasmick, H. G. \& Bursik, R. J. (1990). Conscience, significant others, and rational choice: Extending the deterrence model. Law \& Society Review, 24(3), 837-862.

Hockenberry, S. (2020, June). Juveniles in Residential Placement in 2017 Juvenile Justice Statistics in National Report Series Bulletin. U.S. Department of Justice Office of Justice Programs.

Kanazawa, S. (2008). When crime rates go down, recidivism rates go up. Psychology Today blogs.

Kelley, B., Huizinga, D., Loeber, R., and Thornberry, T.P. (1997). Epidemiology of serious violence, Juvenile Justice Bulletin, June. Office of Juvenile Justice and Delinquency Prevention, Washington, DC.: U.S. Department of Justice.

Larson, S. J. (1997, Fall). Attacking crime or kids? Juvenile justice at the crossroads. In RCY,6 (3).

Laub, J. H., Nagin, D. S., \& Sampson, R. J. (1998). Trajectories of change in criminal offending: Good marriages and the desistance process. American Sociological Review, 63,225-238.

Loeber, R., Farrington, D. P., \& Waschbusch, D.A. (1998). Serious and violent juvenile offenders. Pp. 13-29 in Serious and Violent Juvenile Offenders: Risk Factors and Successful Interventions, R. Loeber and D.P. Farrington, eds. Thousand Oaks, CA: Sage.

MacKenzie, D.L. (2006). What works in corrections? Cambridge Studies in Criminology. New York: Cambridge University Press.

McShane, M. D. \& Williams III, F. P. (1989). The prison adjustment of juvenile offenders. Crime \& Delinquency, 55, 2, 254-269.

Moffitt, T. E. (1993). Adolescence-limited and life-course persistent anti-social behavior: A developmental taxonomy. Psychological Review 100, 674-701.

Mukherjee, S. (1997). Juvenile crime: Overview of changing patterns. Paper presented at the Australian Institute of Criminology Conference Adelaide, Australia.

Mulvey, E. P., Steinberg, L., Cauffman, E., Piquero, A. P., Chassin, L., Brame, R., Schubert, C. A., Hecker, T. \& Losoya. S. H. (2004). Theory and research on desistance from anti-social activity among serious adolescent offenders. Youth Violence and Juvenile Justice. 2, 3, 213-236.

Nagin, Daniel and Joel Waldfogel. (1998). The effect of conviction on income through the life cycle. International Review of Law and Economics, 18, 25-40.

Office of Juvenile Justice and Delinquency Prevention. (2008, August). Juvenile transfer laws: An effective deterrent to delinquency? Juvenile Justice Bulletin. Washington, DC: U. S. Department of Justice.

Office of Juvenile Justice Delinquency Prevention (1999). Juvenile custody rates by states: Statistics briefing book. Washington, DC: U. S. Department of Justice. 
O’Shaughnessy, R. J. \& Andrade, H. (2004). Forensic psychiatry and violent adolescents. Medscape Today, 4. Retrieved from www.medscape.com/viewarticles/571434

Piehl, A.M. (1998). Economic conditions, work, and crime. In M. Tonry (Ed.), Handbook on crime and punishment (pp. 302-319). New York: Oxford University Press.

Redding, R. E. (2008, August). Juvenile transfer laws: An effective deterrent to delinquency? Juveniles Justice Bulletin. Washington, DC: Department of Justice.

Sampson, R. J., \& Groves, W. B. (1989). Community structure and crime: testing social disorganization theory. American Journal of Sociology, 94, 774-802.

Sampson, R. J., \& Laub, J. H. (1995). Understanding variability in lives through time: Contributions of lifecourse criminology. Studies on crime and crime prevention, 4, 143-158.

Sampson, R. J. \& Laub, J. H. (1993). Crime in the making: Pathways and turning points through life. Cambridge, Mass.: Harvard University Press.

Sampson, R. J. \& Laub, J. H. (1990). Crime and deviance over the life course: The salience of adult social bonds. American Sociological Review, 55, 602-627.

Shalala, D. (2001). Youth violence: A report of Surgeon General. Presentation of the Surgeon General's Report on violent careers and anti-social or delinquent behavior. Washington, DC: U. S. Department of Health and Human Services, Office of Juvenile Justice \& Delinquency Prevention. Retrieved form http://sgeropts.nlm.nih.gov/NN/

Siegel, L. J., Welsh, B. C., \& Senna, J. J. (2003). Juvenile delinquency: theory, practice \& law. $8^{\text {th }}$ (Ed.) Belmont: CA.: Wadsworth Publish Company.

Steinberg, L. \& Cauffman, E. (2000). A developmental perspective on jurisdictional Boundary, 383, form Fagan, J. \& Zimring (Eds.) The changing borders of juvenile justice. Chicago Press.

Steinberg, L., Chung, H., \& Little, M., (2004). Reentry of young offenders from the justice system: A developmental perspective. Youth Violence and Juvenile Justice, 2 (1), 21-38.

Steinberg, L., \& Morris, A. S. (2001). Adolescent development. Annual Review of Psychology, 52, 83-110.

The Future of Children. (2008, Fall). Juvenile justice. 18 (2), 1-2. Retrieved from www.futureofchildren.org

Tolan, P. H. (1987). Implications of onset for delinquency risk identification. Journal of Abnormal Child Psychology, 15, 47-65.

Tolan, P.H., \& Gorman-Smith, D. (1998). Development of serious, violent and chronic offenders. In R. Loeber \& D. Farrington (Eds.). Never too early, never too late: Serious, violent, and chronic juvenile offenders. (pp. 68-65). Beverly Hills, CA: Sage

Tyler, T. R. (1990). Why people obey the law? New Haven, Conn.: Yale University Press.

Tyler, T.R., \& Huo, Y.J. (2002). Trust in the Law. N.Y.: Russell-Sage.

Tyler, T. R., Boeckmann, R. J., Smith, H. J., \& Huo, Y. J. (1997). Social justice in a diverse society. Boulder, CO: Westview Press.

United Stated Census Bureau. (2001). Louisiana Census. Washington, DC: U. S. Government Printing Office.

United Stated Census Bureau. (2000). Louisiana Census. Washington, DC: U. S. Government Printing Office.

Van Patten, D. (1995). Match Point Ministry Manual Second Edition, Washington, DC: Prison Fellowship Ministries, 8.

Wilson, D. B., Gallagher, C. A., \& MacKenzie, D. L. (2000, November). A meta-analysis of corrections-based education, vocation, and work programs for adult offenders. Journal of Research in Crime and Delinquency, $37(4), 347-368$. 